\title{
Lords' report criticizes 'underclass' status of UK contract researchers
}

London. A House of Lords report on research careers for graduate scientists calls on universities to upgrade the pay and status of contract researchers whom it describes as the new scientific "underclass".

The 60-page report (Academic Research Careers for Graduate Scientists, HMSO, £12.95), published last week by the House of Lords Select Committee on Science and Technology, warns that the low pay, "gypsy" existence and inferior status of contract researchers - who make up two thirds of research staff in some fields - is undermining the future competitiveness of British science. The absence of a career structure for contract research, it says, once an important staging post on the way to a permanent academic position, is driving the cream of Britain's science graduates into the arms of industry and commerce.

"More than 20,000 contract researchers, most of whom work under conditions inferior to those of established members of academic staff, hardly constitute the best advertisement to attract either the most able science undergraduates into postgraduate work or school leavers to enrol as university students of these subjects," the report says.

"Universities must get their house in order," according to Lord Dainton, the select committee chairman, who is a former chairman of the University Grants Commission and chancellor the University of Sheffield. "For too long they have been getting staff on the cheap, turning them into gypsies by moving them around on shortterm contracts. It is unsettling and an absurdity that will damage science if not rectified."

The report reveals that contract staff now form the bulk of researchers in most science and engineering disciplines. The proportion of contract researchers to total research staff is highest in the fields of biochemistry (64 per cent), pharmacology (61 per cent) and clinical medicine (60 per cent). Metallurgy and materials (58 per cent), pre-clinical studies (56 per cent) and physics (52 per cent) are not far behind. In general women take a proportionately higher share of contracts than men.

Under current practice, research staff recruited on temporary contracts are paid less than their full-time colleagues. According to the Association of University Teachers, "average academic pay is over $£ 27,000$ and average research pay is under $£ 18,000$ ".

Contract researchers, similarly, have no pension provision. They are entitled to few of the benefits enjoyed by their full-time peers and have little guarantee of progression to a full-time post. Statistics on contract staff indicate high turnover among the junior research ranks, but with few filtering through to established positions. Between 1977 and 1994, the numbers of contract researchers at British universities increased by 216 per cent from 5,800 to 18,600 . The rise in permanent teaching and research

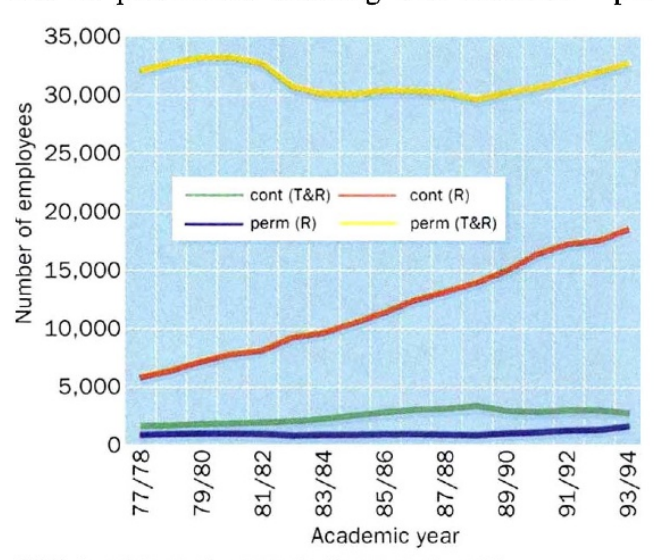

(T\&R: teaching and research. R: research only)

The number of contract researches continues to rise...

positions for the corresponding period is just 2.3 per cent.

The report recommends that universities should earmark bridging funds to tide over staff who find themselves out of work between contracts. It also encourages universities to break out of the 'six-month syndrome' of appointing staff on a string of short-term appointments. They should, instead, initiate longer-term fellowships in

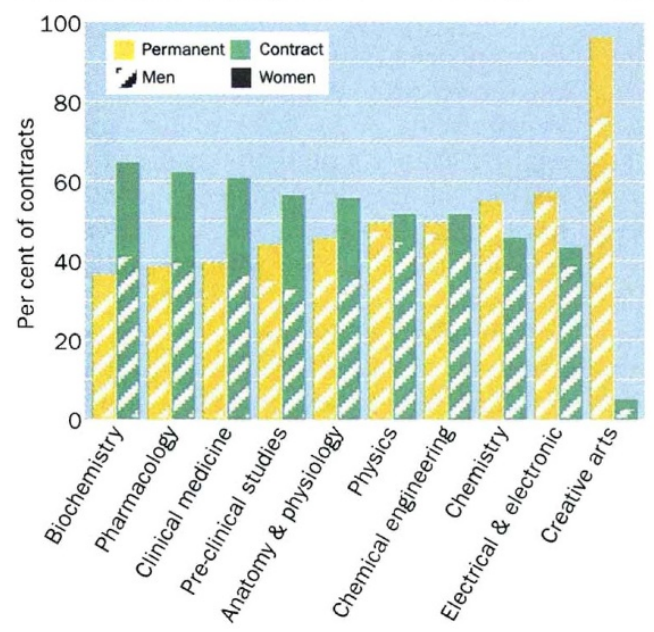

... biological sciences suffer most and women suffer more than men.

line with initiatives already taken by the Wellcome Trust and the University of Warwick.

Interestingly, the report also reproduces evidence from a number of representatives of institutions who pointed out that contract research was not all bad news. The Associa- tion of Medical Research Charities, whose member charities spent $£ 317$ million on research (US\$490 million) in 1993-94, pointed out that short-term research contracts enable "charities to target their support for research to proposals relevant to their objects".

The Royal College of General Practitioners, similarly, said that "a major advantage [of the present system] is that a research worker who goes off the boil or loses enthusiasm or skill can be easily removed without any contractual or redundancy problems".

But in practical terms the report amounts to little more than a set of well-meaning but rather blunt-edged recommendations, which are in danger of being ignored by universities operating in today's climate of too many applicants chasing too few jobs. Signs are already emerging that vacancies for academic staff are likely to rise in the future.

The present bottleneck of staff in the junior ranks is expected to ease within the next decade when a quarter of science and technology academic staff - a legacy of the expansion of higher education during the 1960 s - start to retire. Finally, the present expansion in student numbers at British universities is also expected to generate a separate demand for academic staff.

However, the Association of University Teachers warn that many forthcoming vacancies could be left unfilled unless standards for contract researchers are improved. "Some of these researchers will undoubtedly transfer and take up teaching positions," says its spokeswoman, Monica Hicks. But there will be an inevitable shortfall, she says. "People are leaving contract research because there is a limit to the numbers of six-month contracts they are going to tolerate."

The House of Lords report is the second investigation into contract research to be published in the space of a month. The Committee of Vice Chancellors and Principals of UK universities, the Royal Society and the research councils published a joint draft 'concordat' at the end of July aimed at improving the career management and prospects of contract research staff (See Nature 376, 289; 1995). This document, which is based on a proposal in the 1993 science white paper, Realising Our Potential, has been distributed for comment to universities and research councils. It should be finalized by the end of this year.

Ehsan Masood 